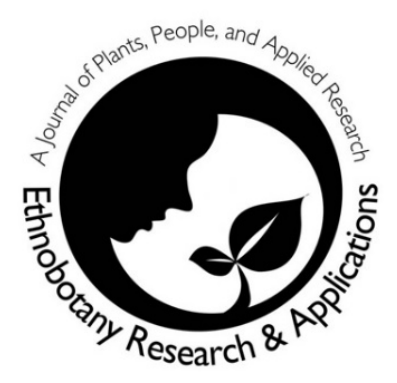

\title{
Traditional method of hunting edible termite, Odontotermes formosanus Shiraki by the Irulars of Gingee hills, South India
}

\author{
Muruganandam S, Ravikumar S, Dhamotharan R and \\ Ayyanar M
}

\section{Databases and Inventories}

\begin{abstract}
Background: Insects, especially termites are considered as one of the nutritious foods widely used by various ethnic communities throughout the world. Present study was undertaken among rural people in Gingee hills of Eastern Ghats, India to know about traditional hunting method for edible termites (Odontotermes formosanus Shiraki) practiced by them to fulfill their protein requirement and as a source of revenue.
\end{abstract}

Methods: Traditional method of hunting edible termites by Irulars of Periyamalai was observed for a couple of years. Preparation of herbal mixture, trapping method and other information were documented through direct observation in the field and by interviewing the individuals involved in termite hunting.

Results: A total of 11 plant species were found to be used in termite hunting process and to treat diseases or allergies occurred (if any) after consumption of termites. Powdered roots of Aristolochia indica L., seeds of Canavalia cathartica Thouars and leaves of Glycosmis mauritiana (Lam.) Tanaka, are used to harvest termites from their mounds and to treat poisonous bites. Acalypha fruticosa Forssk., Leucas aspera (Willd.) Link., Madhuca longifolia (J. Koenig ex L.) J.F. Macbr. Pavetta indica L. and Premna tomentosa Willd. are used by Irulars in treating skin allergic conditions after consuming termites.

Conclusions: Traditional method of hunting edible termites with medicinal plants shows the rich traditional knowledge of the Irulars. There should be initiatives to identify and quantify the nutritional and nutraceutical value of termite species used by ethnic people for value addition, which in turn improve their livelihood. Also, it is essential to study the plants employed in termite hunting for their wound healing potential.

Key words: Eastern Ghats; Gingee hills; Irulars; Odontotermes formosanus; Termites

\section{Correspondence \\ Muruganandam S \\ Ravikumar S \\ Dhamotharan $\mathbf{R}$ \\ Department of Plant Biology and Plant Biotechnology, Presidency College (Autonomous), Chennai - 600 005, India \\ Ayyanar $\mathbf{M}^{*}$ \\ Department of Botany and Microbiology, A.V.V.M. Sri Pushpam College (Autonomous), Poondi - 613 503, Thanjavur, India \\ *Corresponding author: asmayyanar@yahoo.com \\ Ethnobotany Research \& Applications 18:10 (2019)}

\section{Background}

Insects play a major role in the lives of human beings, as pests and disease transmitting vectors (Chakravorty 2014). However, not all insects are pests or vectors and majority are harmless and beneficial. Significance of insects as food and medicine is not surprising, since this group has highest number of species, in nature (Figueiredo et al. 2015). Interest in use of insects as food has accelerated greatly in recent years due to its nutritional and environmental advantages over conventional sources of protein from other sources (Tan et al. 2017). 
Insects are reported to be readily available source of protein, lipids, carbohydrates, vitamins, minerals; they are good sources of essential amino acids and polyunsaturated fatty acids (Zielinska et al. 2015). Insect proteins hold nutritional advantageous in terms of total protein content and essential amino acid profiles over plant proteins obtained from various cereals, legumes, beans, lentils, soybean, etc. (Sun-Waterhouse et al. 2016).

Practice of using insects as a part of human diet is referred as entomophagy which plays an important role nutritional security in Africa, Asia and Latin America (Meyer-Rochow 2010). Entomophagy is commonly influenced by various cultural and religious practices. There are many studies about the nutritive value of edible insects especially which are harvested in nature. It is estimated that over 2000 species of insects are consumed by over two million people all over the World especially in several countries across Asia, Africa and America (van Huis et al. 2013; Chakravorty et al. 2016). Worldwide, most commonly consumed insects are beetles $(31 \%)$, caterpillars $(18 \%)$, bees, wasps and ants $(14 \%)$, grasshoppers, locusts and crickets $(13 \%)$, cicadas, leafhoppers, plant hoppers, scale insects and true bugs $(10 \%)$, termites $(3 \%)$, dragonflies (3\%), flies $(2 \%)$, and other insects $(5 \%)$ (Zielinska et al. 2015).

Termites are cosmopolitan in distribution and are known to build termite mounds. Termite mounds are conspicuous features in tropical soils which differ from their parent soils in physical, chemical and biological properties. Hence, termites are often referred as major bioturbators, soil engineers or even master builders (Shanbhag et al. 2017). Termites are one of the most influential soil-dwelling ecosystem engineers, whose biogenic structures modify the availability of resources for other organisms. During their feeding and nesting activities in mounds, they improve soil aeration, enhance absorption and storage of water, facilitate carbon fluxes and storage (Kaiser et al. 2017). At the same time, several termite species cause extensive damage to timbers, buildings, crops and forest trees (Akhtar \& Shahid 1988) and also have a major role in decomposition of organic matter.

Several species of termites are commonly used in traditional medicine to treat various diseases like influenza, asthma, bronchitis, whooping cough, sinusitis, tonsillitis and hoarseness (Figueiredo et al. 2015). They also act as a vital source of food in improving human diet, especially who suffer from malnutrition due to a deficit of protein, as they considered as nonconventional food with great economic and social importance. Odontotermes is one of the commonly used edible termite genera in traditional medicine and are available abundantly during the rainy season.

Indian subcontinent has diverse physical and climatic features offering favourable conditions to support rich and varied termite fauna with about 300 species (Kumari et al. 2009). The winged termites (Eesal in Tamil) are collected and sold in market by tribal people, 'Irumbas' of Tamil Nadu and in some villages of nearby state Karnataka. The queen termite is collected by underprivileged people and fed as tonic for tweak children. Traditionally, local people consume the fried termites along with pulses, spices and salt to enhance taste in some south Indian villages (Rajan 1987).

Irulars in Pakkamalai reserve forest of Eastern Ghats have own traditional culture and beliefs. Their chief source of livelihood is rice and feast with winged white ants (termites) which they hunt at the time of their seasonal outbreak. Some Irulars are herbalists. They have sound knowledge on folk medicinal practices especially in treating snakebite and insect stings (Thurston 2013). Most of the herbalist Irulars keep their folk knowledge within themselves and are not interested in disclosing it to fellow community members (Sureshkumar et al. 2017; Silambarasan et al. 2017). So, it is necessary to document folk knowledge held by present day generation before such knowledge vanishes.

Ethnobiological studies describing the use of termites (food and medicine) for human and livestock are mostly from American and African countries. Existence of rich diversity of insects (including termites) with edible potential is recorded in most of the Asian countries like India and China but there is a lacuna in availability of published reports about the utility of termites except a few studies. In view of this, the present study has been undertaken to explore folk knowledge about traditional hunting method for edible termites by Irulars in Gingee hills of southern Eastern Ghats, India. We document information on the medicinal plant extracts used for hunting edible termites and plant extracts used to treat skin allergies (if any) arising after termite consumption.

\section{Materials and Methods}

\section{Study Area}

The study area Periyamalai is situated in Pakkamalai reserve forest of Gingee hills (Eastern 
Ghats) in Villupuram district of Tamil Nadu, India, located between $12^{\circ} 10^{\prime} \mathrm{N}$ and $79^{\circ} .17^{\prime} \mathrm{E}$ (Fig.1). The area receives maximum rain fall during northeast monsoon from September to December every year. The hill is located at a distance of $160 \mathrm{~km}$ southwest from the state capital Chennai. Villupuram district is bounded by Bay of Bengal and union territory of Puducherry in east; Kanchipuram and Tiruvanamalai districts in north; Cuddalore district in south; Dharmapuri and Salem districts in west.

Geographically, Villupuram district appears to be sloping towards south-east and consists of sedimentary rocks. Pennaiaru, Gadilam, Gomukhi, Malattaru and Sankaraparani are the rivers flow through the district. Coastal length of this district is about $30 \mathrm{~km}$ and northeastern part of district has many isolated hillocks called Kalvarayan hills. The forest range of Gingee hills has seven reserved forests and lots of isolated, small hillocks as a part of Eastern Ghats.

Ethnobotanical explorations in the study area covering 17 villages were undertaken from June 2014 to August 2016. Season specific visits with 25 field days from 17 visits were made during southwest monsoon when Irulars usually hunt winged termites. Preparation of herbal plant mixture, trapping method and other information were recorded through direct observation in the field and through conversation with the Irulars involved in termite hunting.

Among the studied villages, Cithravarai village is a historic place with rock paintings of Lord Ayyanar (Fig. 2a). Ancient rock forts, traditional temples, rock statues and terracotta (sand made horses) are also recorded from the study area (Fig. 2b). Hills present in study area are considered as sacred sites. We observed nearly 20 dolmens and six dolmenoid cists on hilltops which are locally called as sanjeevi-malai or periya-malai (Fig. 2c). These dolmens and dolmenoids are U-shaped burial portholes.

The Irular Community

Ethnic people in the study area are locally referred as Poosaali or Posaari or Irular. Irulars are sporadically distributed in northern parts of Tamil Nadu with varied population range. Their major settlement is in the town of Chenglepet which is about $75 \mathrm{~km}$ away from Chennai. Irulars are similar to Negrio tribes existing in various parts of India (Sinnu 2013). They offer wild rice to the goddess Kannimmar, worshipped by them for several decades. Children of nearly $50 \%$ respondents are school drop-outs due to poverty and work as labourers.

The collected plant species were identified taxonomically using The Flora of Presidency of Madras (Gamble 1935) and The Flora of Tamilnadu Carnatic (Matthew 1983). The plant specimens were preserved and deposited in the herbarium of Department of Plant Biology \& Plant Biotechnology, Presidency College, Chennai for future reference. Scientific names of identified species were confirmed with the standard taxonomic database 'Plant List' (www.theplantlist.org). Termite species consumed by Irulars was identified by Dr. Gabriel Paulraj, Scientist, Entomology Research Institute, Loyola College, Chennai, India.

For carrying out field studies for documenting folk uses from the Irulars in the study area, we followed the recommendations of Heinrich et al. (2017). The Irular people of study area have been duly acknowledged, and the results have been intimated with the participants involved in the study according to "The Code of Ethics" of the International Society of Ethnobiology (2006).

\section{Results}

\section{Medicinal plants used in termite trapping}

Traditional method of hunting edible termites by Irulars using plant extracts were observed for two years and hunting practices were recorded from 36 people in the study area aged between 31 and 65 . The selection of studied people is based on their regular practice of hunting termites in the study area over the years. During the course of investigation, we observed that Irulars used 11 plant species for hunting the edible termite, Odontotermes formosanus (Table 1).

Out of the 11 plant species used for hunting Odontotermes formosanus, three are used for termite trapping from termite mounds and to treat poisonous bites, three species are used as flavoring agents in curry preparations that include termites and remaining five species are used to treat allergies/illnesses (if any) caused after consumption of termites. These plants belonged to eight families, viz., Rutaceae (with 4 species), Aristolochiaceae, Euphorbiaceae, Fabaceae, Lamiaceae, Rubiaceae, Sapotaceae and Verbenaceae (with one species each). 


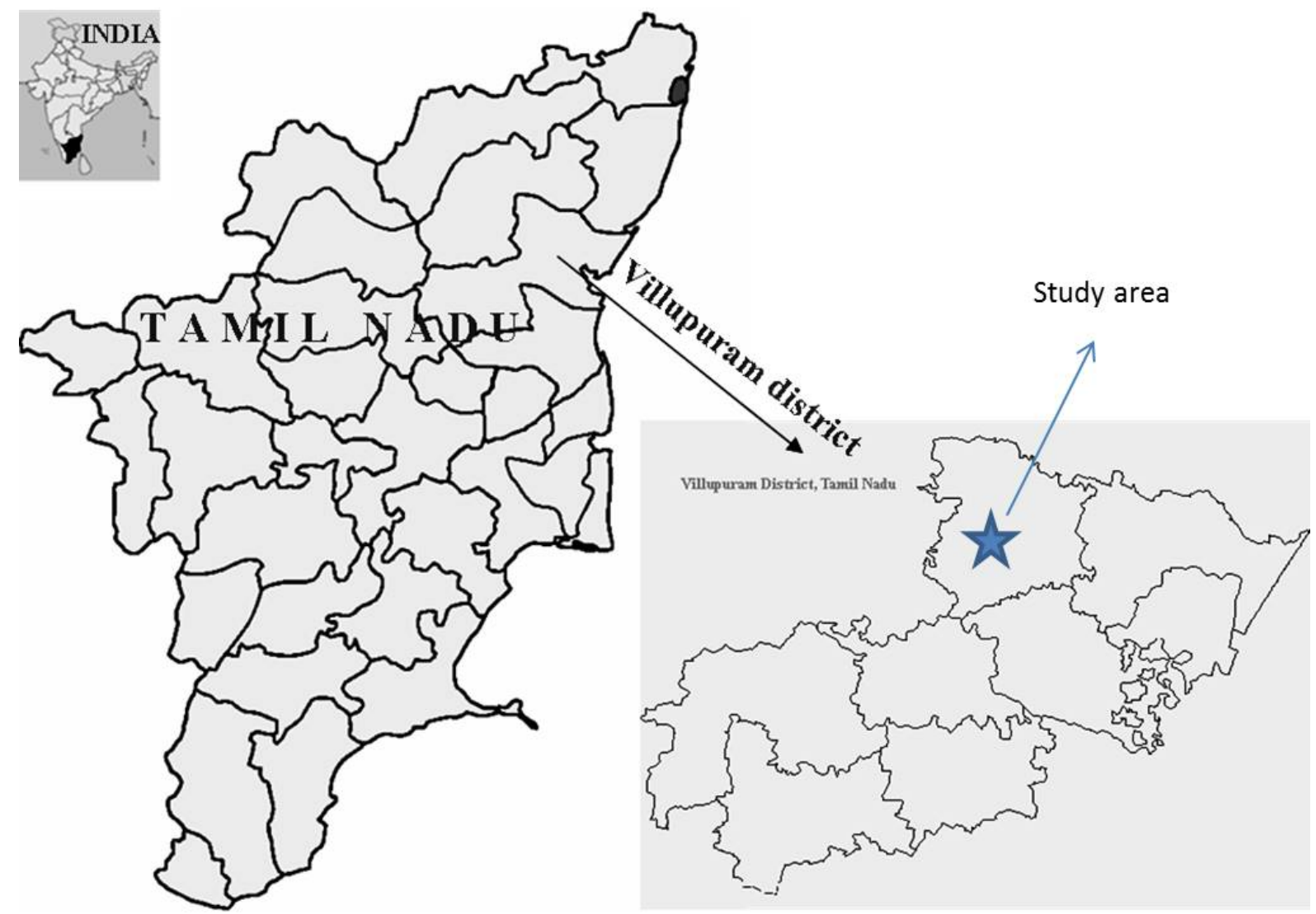

Figure 1. Location map of study area in Tamil Nadu, India

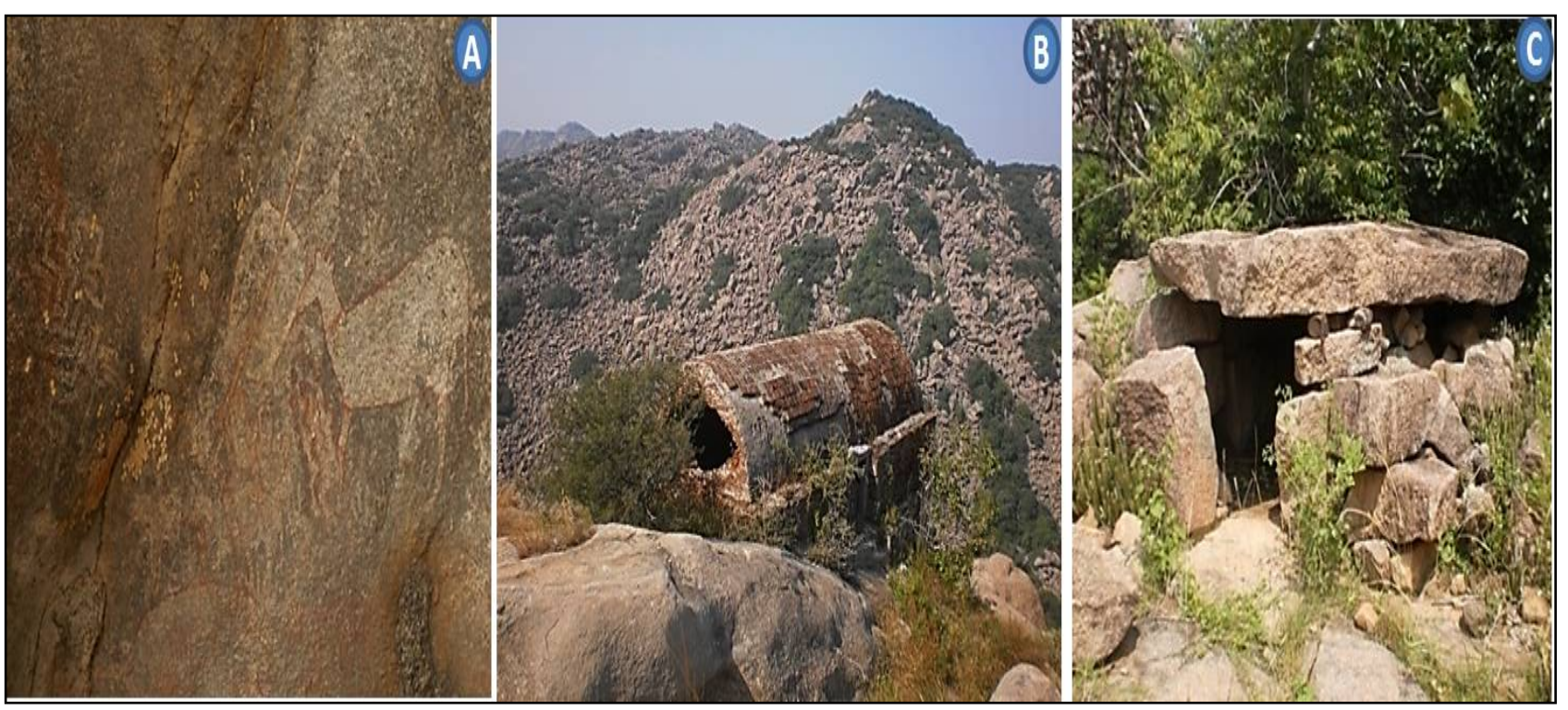

Figure 2. (a) Traditional rock paintings in the study area; (b) Ancient rock fort in one of the villages of study area; (c) Dolmen remnant in the hilltop of study area. 
Table 1. List of medicinal plants used in hunting edible termites and to treat illnesses formed after consumption of termites.

\begin{tabular}{|c|c|c|c|c|}
\hline Botanical name \& family & Local name & $\begin{array}{l}\text { Parts } \\
\text { used }\end{array}$ & Mode of administration & Uses \\
\hline $\begin{array}{l}\text { Aristolochia indica L. } \\
\text { (Aristolochiaceae) }\end{array}$ & Perungayaveru & Root & $\begin{array}{l}\text { Fried root powder is mixed } \\
\text { with powdered seeds of } C \text {. } \\
\text { cathartica and leaves of } G \text {. } \\
\text { mauritiana. }\end{array}$ & $\begin{array}{l}\text { Termite harvest/ } \\
\text { poisonous bites }\end{array}$ \\
\hline $\begin{array}{l}\text { Canavalia cathartica Thouars } \\
\text { (Fabaceae) }\end{array}$ & Eesakottai & Seed & $\begin{array}{l}\text { Fried seed powder is mixed } \\
\text { with root of } A \text {. indica and } \\
\text { leaves of } G \text {. mauritiana. }\end{array}$ & $\begin{array}{l}\text { Termite harvest/ } \\
\text { poisonous bites }\end{array}$ \\
\hline $\begin{array}{l}\text { Glycosmis mauritiana (Lam.) } \\
\text { Tanaka (Rutaceae) }\end{array}$ & Eesakotai thalzai & Leaf & $\begin{array}{l}\text { Fried leaf powder is mixed } \\
\text { with root of } A \text {. indica and } \\
\text { powdered seeds of } C \text {. } \\
\text { cathartica. }\end{array}$ & $\begin{array}{l}\text { Termite harvest/ } \\
\text { poisonous bites }\end{array}$ \\
\hline $\begin{array}{l}\text { Clausena dentata (Willd.) } \\
\text { Roem. (Rutaceae) }\end{array}$ & Konjee & Leaf & $\begin{array}{l}\text { Termites are fried with raw } \\
\text { leaves after removing wings } \\
\text { for consumption. }\end{array}$ & Flavor \\
\hline $\begin{array}{l}\text { Limonia acidissima Groff } \\
\text { (Rutaceae) }\end{array}$ & Tharavealam & Leaf & $\begin{array}{l}\text { Termites are fried with raw } \\
\text { leaves after removing wings } \\
\text { for consumption. }\end{array}$ & Flavor \\
\hline $\begin{array}{l}\text { Toddalia asiatica (L.) Lam. } \\
\text { (Rutaceae) }\end{array}$ & Milagaranai & Leaf & $\begin{array}{l}\text { Termites are fried with raw } \\
\text { leaves after removing wings } \\
\text { for consumption. }\end{array}$ & Flavor \\
\hline $\begin{array}{l}\text { Acalypha fruticosa } \\
\text { Forssk.(Euphorbiaceae) }\end{array}$ & Sinnee & Leaf & $\begin{array}{l}\text { Leaf paste is taken orally in } \\
\text { small quantities. }\end{array}$ & Skin allergy \\
\hline $\begin{array}{l}\text { Leucas aspera (Willd.) Link } \\
\text { (Lamiaceae) }\end{array}$ & Thumbai & Leaf & $\begin{array}{l}\text { Leaf paste is taken orally in } \\
\text { small quantities. }\end{array}$ & Skin allergy \\
\hline $\begin{array}{l}\text { Madhuca longifolia (J.Koenig } \\
\text { ex L.) J.F.Macbr. } \\
\text { (Sapotaceae), }\end{array}$ & Iluppai & Leaf & $\begin{array}{l}\text { Leaf paste is taken orally in } \\
\text { small quantities. }\end{array}$ & Skin allergy \\
\hline Pavetta indica L. (Rubiaceae) & Pavattai & $\begin{array}{l}\text { Young } \\
\text { stem }\end{array}$ & $\begin{array}{l}\text { Paste of young shoot is } \\
\text { taken orally in small } \\
\text { quantities }\end{array}$ & Skin allergy \\
\hline $\begin{array}{l}\text { Premna tomentosa Willd. } \\
\text { (Verbenaceae) }\end{array}$ & Pudangai-naari & Leaf & $\begin{array}{l}\text { Leaf paste is taken orally in } \\
\text { small quantities. }\end{array}$ & Skin allergy \\
\hline
\end{tabular}



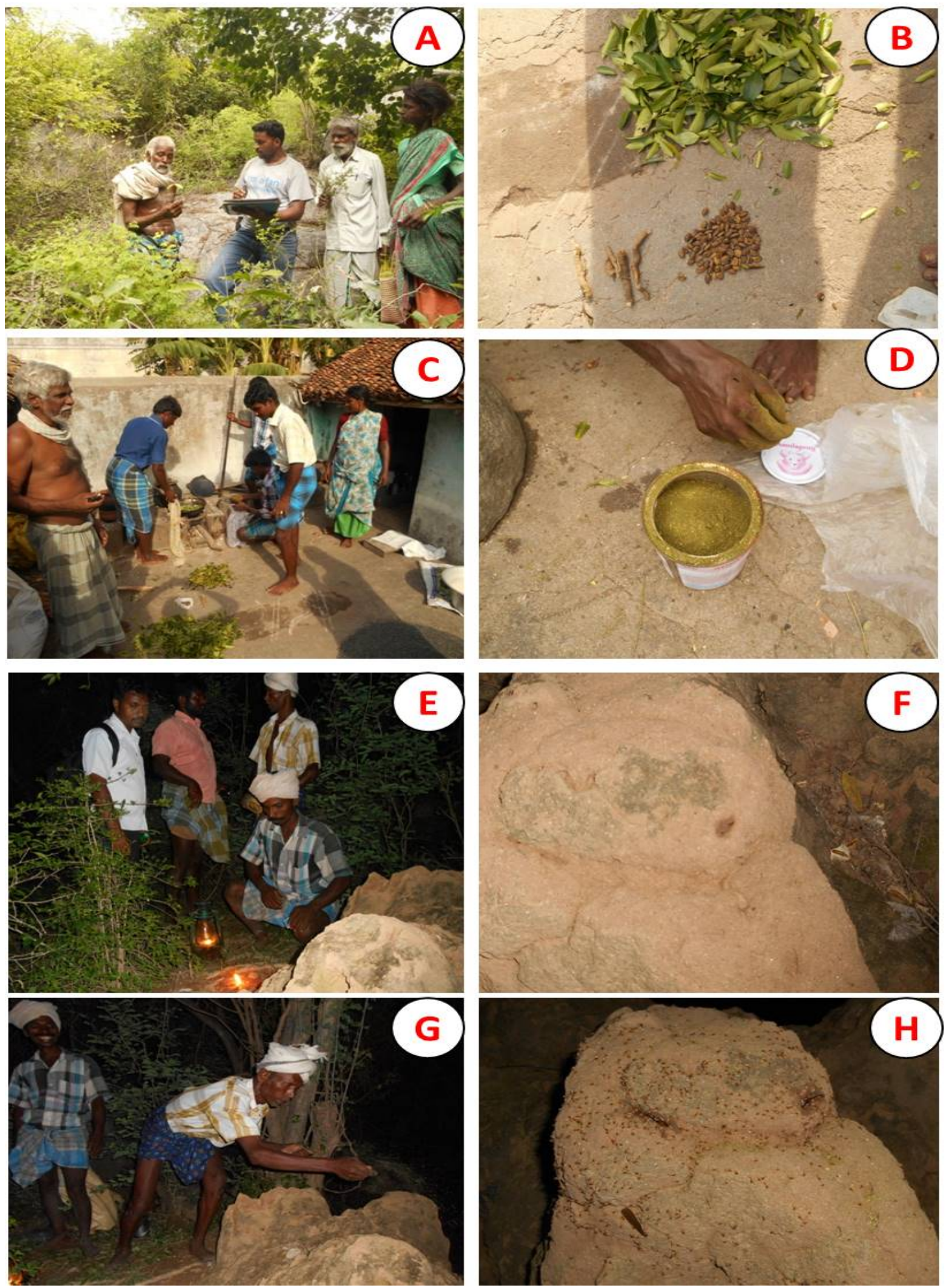

Figure 3. (a) Documenting ethnomedicinal information from Irulars (b) Plants parts employed in termite hunting; (c) Preparation of powdered plant mixture; (d) Packaging and preserving powdered plant mixture; (e) \& (f) Identification of termite mounds (g) Sowing powdered plant mixture on termite mounds; (h) Emergence of termites from the mounds 

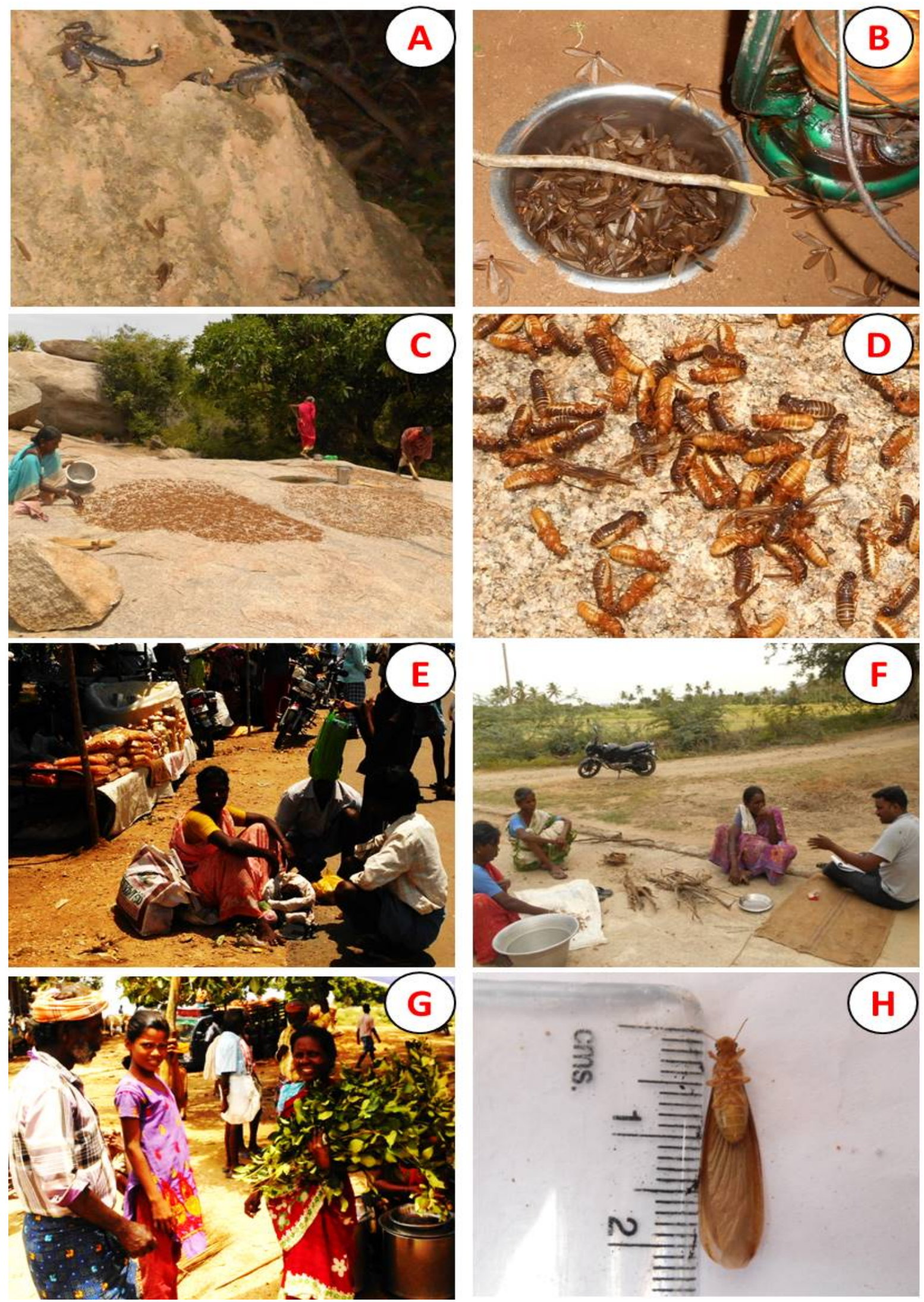
(c) \& (d) Wing removed termites preserved for drying; (e) Selling processed termites; (f) \& (g) Retailing herbal raw materials by Irulars in local market; (h) Measuring the termite 


\section{Preparation of herbal extracts}

For hunting edible termites, Irulars use roots of Aristolochia indica, seeds of Canavalia cathartica and leaves of Glycosmis mauritiana which are collected from Pakkamalai reserved forest of Gingee hills. Healthy and fresh plant parts of above three plants are collected, shade dried separately and mixed together in a ratio of 10:20:70 (Fig.3 ad). They usually prepare powdered mixture of above plants during the month of June due to availability of sufficient quantity of these plants in this period. Prepared powder mixture is then retained for collecting termites during favourable season. During the first rainy season (June to August; south west monsoon), Irular begin exploring for termite mounds.

\section{Termite trapping method}

The termite mound is identified by signs such as 'varvou' on mounds, i.e., mounds having small patches of wet soils and slightly swelled surfaces on mounds (Fig. 3 e, f). After identifying mounds for termite hunting, Irulars prepare themselves to harvest termites usually at night time. The Irular perform rituals before harvesting at the site of mound following which they blow powdered mixture of plant materials (50 to $150 \mathrm{~g}$, based on the size of mound) into the mound for two to three times with 15 minutes intervals (Fig. $3 \mathrm{~g}$ ). At a little distance from the mounds, they dig a small hole to fix a vessel to lure termites. A cross stick is fixed above the vessel and a burning lamp is placed above the cross stick to attract termites emerging out of mound after the powdered plant mixture was blown over the termite mound. The wingless termites are the ones to come out first; they then make a small hole which facilitates winged termites to emerge out of the mound (Fig. $3 \mathrm{~h}$ ). After a while, a large number of wingless and winged termites emerge from the mound and only winged termites get attracted by the burning lamp and fall into the vessel.

During the termite hunting process, some poisonous snakes, scorpions and lizards also approach the mounds to prey on the termites for their nourishment (Fig. 4 a). Irulars drive away these poisonous animals instead of killing. Poisonous bites and stings sustained in the process are treated by consuming the same powdered herbal extracts blown into the mound with water or honey. About 1-3 kg of winged termites can be harvested in a night from a particular mound and non-winged termites will not trapped by the Irulars (Fig. 4 b). Both winged and wingless termites are alive at the time of collection, but they become unconscious due to continuous application of powdered plant materials on mounds. Environmental conditions too had a major role in harvesting termites especially, a mild-air-current and minimal moon-light are crucial to pursue termite hunting. Most of them prefer dark moon lunar phase (locally referred as 'Amavasya' for hunting termites.

\section{Consumption of termites}

Termites are rich in nutrients and are good source of proteins. Irulars collect only winged termites, sun dry them and remove their wings (Fig. $4 \mathrm{c} \& \mathrm{~d}$ ). The fried termites are ready to eat and may be consumed directly or along with other homemade dishes. After the removal of wings, termites are fried with leaves of Toddalia asiatica, Limonia acidissima and Clausena dentata as flavouring agents (Table 1). The wingless termites are also packed and taken to nearest markets such as Vettavalam, Thallakulam, Kandachipuram and Gingee for sales and this provides livelihood opportunity for some of the Irulars who are inhabitants of forests (Fig. 4 e).

Post-consumption of termites, some individuals may develop skin allergies or digestive problems. During such instances, equal amount of leaves of Madhuca longifolia, Premna tomentosa, Leucas aspera, Acalypha fruticosa and Pavetta indica are mixed together, made into a paste and applied topically for skin allergies. The same plant mixtures can be taken orally to treat diseases caused due to consumption of termites. Hence, these plant materials are also sold by Irulars along with the termites in the market (Fig. $4 \mathrm{f} \& \mathrm{~g}$ ). Some developing dysentery or digestion related problems are advised to consume buttermilk to get relief from such diseases. Average length of collected termite species (Odontotermes formosanus) is $\sim 22 \mathrm{~mm}$ with wings and $\sim 11 \mathrm{~mm}$ without wings (Fig. $4 \mathrm{~h}$ ).

\section{Discussion}

Edible insects represent a novel and sustainable protein source for humans and have enormous potential as ingredients for foods. Hence, there is support for 'the use of insects for foods' (SunWaterhouse et al. 2016). Utilization of insects for medicine is known as entomotherapy (Costa-Neto 2005). Termites have been consumed for generations in many parts of the world and practice of termite hunting has increased in recent years (Figueiredo et al. 2015). 
Studies have shown that Irulars of Red hills (Bosco \& Arumugam 2012), Pillur valley (Rasingam 2012) and Erode district (Revathi \& Parimelazhagan 2010) of Tamil Nadu possess rich ethnobotanical knowledge. Besides this, local people residing close to Gingee hills are also reported to have rich knowledge on medicinal plants (Muralidharan \& Narasimhan 2012; Arulappan et al. 2015; Muruganandam et al. 2016).

Many south Indian tribes including Kanikaran, Paniyan, Sholaga, Irula and Kota have been using the termite, Odontotermes formosanus to treat asthma and viral infections (Wilsanand 2005). We observed that, several plant species are used by Irulars while hunting edible termites from their environs. Irulars frequently use roots of Aristolochia indica, seeds of Canavalia cathartica and leaves of Glycosmis mauritiana for of harvesting edible termites as well as to treat poisonous bites while hunting termites in the field. It has been scientifically proven that, $A$. indica is effective in treating wounds, inflammations, poisonous bites and stings and also used as mild sedative in various traditional practices (Shafi et al. 2002). The major active chemical constituents of $A$. indica are aristolochic acid and aristolactams (Khare 2007). Chander et al. (2015) reported that $C$. cathartica is widely used by Nicobarese group of tribal communities to treat body pain, earache, fever and joint pain. Methanol extract of cooked and fermented seeds of the plant are also reportedly effective in inhibiting cancer cell lines (Niveditha et al. 2013). Kani tribal communities in Tirunelveli hills of southern India use leaves of $G$. mauritiana to treat fever, cough and cold (Ayyanar 2008).

Termites are considered as a culinary delicacy in most countries of Asia and Africa amongst economically weak societies especially who are inhabited in forest regions. Edible termites provide significant amount of protein, carbohydrates, fat and many essential amino acids and thus can be valuable staple food to pregnant women and children as well as other primates (Paul 2011). In general, several species of Odontotermes are rich in minerals like $\mathrm{Fe}$ and $\mathrm{Zn}$ that represent core public health problems in most of the developing and poor countries (Chakravorty et al. 2016). Use of termite species as medicine has been recorded from 29 countries over three continents (Figueiredo et al. 2015). Of the several medicinally important termite species, majority of records are from Brazil with seven edible termite species suggesting that the use of termites in Brazilian ethnic medicine is relatively common followed by ethnic practices in other countries such as India, Zambia and Nigeria.
Irulars in Tamil Nadu are experts in exploiting this resource with their peculiar style of termite hunting. In urban areas, usually termites are attracted to electric light and trapped in water pans placed by local people at light source and in rural regions termites are trapped while emerging from their mounds (Mahapatro 2015).

Termites have a major role in ethnic cultures, widely used in traditional medicinal systems and also consumed by humans in several parts of the world (Figueiredo et al. 2015). Ancient palm leaf scripts literature available in India also state much about the medicine obtained from these insects. At least 45 species of termites are recorded as being used by human populations with 43 species used in human diet or for livestock feeding, and nine species used as therapeutic agents throughout the World (Figueiredo et al. 2015). Tribal communities in eastern Arunachal Pradesh use only the head part of insects either raw or roasted while other tribes in the state utilize whole organisms (Chakravorty et al. 2016). On the basis of chemical analyses, Odontotermes sp. is suggested as a nutritional supplement to combat malnutrition among Arunachal Pradesh's inhabitants. Irulars in the present study use the plants Acalypha fruticosa, Leucas aspera, Madhuca longifolia, Pavetta indica and Premna tomentosa in treating skin allergies if any which occurred after consuming termites. Roasted termites (Macrotermis spp.) are administered as tonic to children with rice or maize. It has also been reported that, honey mixed termite powder is used to treat wheezing, bronchial problems, cough, etc. (Singh \& Padmalatha 2004).

Chakravorty et al. (2016) reported that, two kinds of edible insects such as Oecophylla smaragdina, an weaver ant and the termite, Odontotermes sp. are consumed by almost all tribes in Arunachal Pradesh (a north-eastern state of India). In the present study, Irulars frequently use the leaves of Toddalia asiatica, Limonia acidissima and Clausena dentata (all belongs to Rutaceae) as flavouring agents during curry preparation with collected edible termites. Presence of significant amount of essential oils in members of Rutaceae is an indication for their predominant use as flavouring agents by the studied ethnic people and also these plants are found abundantly in the study area. Several pharmacologically active constituents are isolated from different plants of Rutaceae viz., phenylpropanoids (Wu et al. 1993), methoxyflavones (Simonsen et al. 2003), furoquinoline alkaloids (Bowen \& Osborne 1998), coumarins (Bowen \& Perera 1982) and are reported to treat neurodegenerative disorders (Alzheimer, 
parkinson disease, multiple sclerosis and down syndrome), inflammation, viral infections, autoimmune pathologies, and digestive system disorders like gastrointestinal inflammation (Bowen \& Patel 1986).

\section{Conclusions}

Aristolochia indica, Canavalia cathartica and Glycosmis mauritiana are found to be used as agents for hunting edible termites by the Irulars in the present study. So, it is necessary to identify the active biomolecules responsible for sedating the termites. Also, it is necessary to study the plants which are employed in termite hunting for their wound healing potential. Traditional method of harvesting edible termites with medicinal plants documented in this study show Irulars have much folkloric potential on herbal medicines as well as food medicines. It can be concluded that processing edible insects like termites into conventional consumer products could encourage entomophagy, which in turn could lead to income generation opportunities. Entomophagy could be the key in solving the world's food and nutrition concerns such as under nutrition or starvation.

\section{Declarations}

List of abbreviations: Not applicable

Ethics approval and consent to participate: The study conforms to "The Code of Ethics" of the International Society of Ethnobiology (2006). Prior Informed Consent was obtained from all participants.

\section{Consent for publication: Not Applicable}

Availability of data and materials: The manuscript contains all relevant data

\section{Competing interests: None declared.}

Funding: None

\section{Authors' contribution}

All the authors contributed equally in survey for collection of folk knowledge, preparation, writing and final drafting of the manuscript.

\section{Acknowledgements}

The authors are grateful to resource persons of the study area for revealing their folk knowledge about termite hunting and their co-operation during the field study, without which this study would not have been achievable. The first author would like to thank M. Kalyanasundaram and Venkatraj for their help rendered during the field work. The authors gratefully acknowledge Dr. P.T. Devarajan, Associate Professor of Botany, Presidency College, Chennai for his cordial help in identification of plant species and suggestions on drafting this article.

\section{Author affiliations \\ Muruganandam $\mathrm{S}^{1}$ \\ Ravikumar $S^{1}$ \\ Dhamotharan $\mathrm{R}^{1}$ \\ Ayyanar $\mathrm{M}^{2 *}$}

${ }^{1}$ Department of Plant Biology and Plant Biotechnology, Presidency College (Autonomous), Chennai - 600 005, India

${ }^{2}$ Department of Botany and Microbiology, A.V.V.M. Sri Pushpam College (Autonomous), Poondi - 613 503, Thanjavur, India

*Corresponding author: asmayyanar@yahoo.com

\section{Literature cited}

Akhtar MS, Shahid AS. 1988. Studies on population density of Odontotermes lokanadi, Chatterjee and Thakur in the New Campus area, Lahore. Pakistan Journal of Zoology 20(2): 177-189.

Arulappan MT, John Britto S, Ruckmani K, Mohan Kumar R. 2015. An ethnobotanical study of medicinal plants used by ethnic people in Gingee hills, Villupuram district, Tamil Nadu, India. American Journal of Ethnomedicine 2(2): 84-102.

Ayyanar M. 2008. Ethnobotanical wealth of Kani tribe in Tirunelveli hills. Ph.D. Dissertation, University of Madras, Chennai, India.

Bosco FG, Arumugam R. 2012. Ethnobotany of Irular tribes in Redhills, Tamil Nadu, India. Asian Pacific Journal of Tropical Biomedicine S874 S877.

Bowen IH, Osborne SJ. 1998. Phytochemical studies in the genus Maclurodendron (Rutaceae): Furoquinoline alkaloids of Maclurodendron magnificum \& Maclurodendron porteri. Journal of Pharmacy and Pharmacology 50: 233- 237.

Bowen IH, Patel YN. 1986. Acridone alkaloids from Pleiospermium alatum. Phytochemistry 25(2): 42931. 
Bowen IH, Perera KPWC. 1982. Alkaloids, coumarins and flavonoids of Micromelum zeylanicum. Phytochemistry 21(2): 433 - 437.

Chakravorty J. 2014. Diversity of Edible Insects and Practices of Entomophagy in India: An Overview. Journal of Biodiversity and Bioprospecting Development 1:124.

Chakravorty J, Ghosh S, Megu K, Jung C, MeyerRochow VB. 2016. Nutritional and anti-nutritional composition of Oecophyllas maragdina (Hymenoptera: Formicidae) and Odontotermes sp. (Isoptera: Termitidae): Two preferred edible insects of Arunachal Pradesh, India. Journal of Asia-Pacific Entomology 19: 711-720

Chander PM, Kartick C, Vijayachari P. 2015. Herbal medicine \& healthcare practices among Nicobarese of Nancowry group of Islands - an indigenous tribe of Andaman \& Nicobar Islands. Indian Journal of Medical Research 141: 720-744.

Costa-Neto EM. 2005. Entomotherapy or the medicinal use of insects. Journal of Ethnobiology 25: 93-114.

Figueiredo RECR, Vasconcellos A, Policarpo LS, Alves RRN. 2015. Edible and medicinal termites: a global overview. Journal of Ethnobiology and Ethnomedicine 11: 29.

Gamble JS. 1935. The Flora of the Presidency of Madras, Adlard \& Son Ltd., London, UK.

Heinrich M, Lardos A, Leonti M, Weckerle C, Willcox M, Applequist W, Ladio A, Long, CL, Mukherjee P, Stafford G. 2017. Best practice in research: Consensus Statement on Ethnopharmacological Field Studies. Journal of Ethnopharmacology 211: 329-339.

International Society of Ethnobiology. 2006. ISE Code of Ethics (with 2008 additions). http://ethnobiology.net/code-of-ethics/

Kaiser D, Lepage M, Konate S, Linsenmair KE. 2017. Ecosystem services of termites (Blattoidea: Termitoidae) in the traditional soil restoration and cropping system Zai in northern Burkina Faso (West Africa). Agriculture, Ecosystem and Environment 236: 198-211.

Khare CP. 2007. Indian Medicinal Plants - An illustrated dictionary. Springer Science + Business Media, LLC, Spring Street, New York, USA.
Kumari M, Sharma VL, Sodhi M, Mukesh M, Shouche Y, Sobti RC. 2009. PCR-SSCP and sequence analysis of three Odontotermes spp. (Order: Isoptera; Family: Termitidae) on the basis of partial 16SrRNA gene. Molecular and Cellular Biochemistry 330: 153 - 162.

Mahapatro, G.K., 2015. Ethno-entomology: Termites as food and medicine. Current Biotica $9(1): 5-8$.

Matthew KM. 1983. The Flora of the Tamil Nadu Carnatic. The Rapinat Herbarium, St. Joseph's College, Tiruchirapalli, India.

Meyer-Rochow VB. 2010. Entomophagy and its impact on world cultures: the need for a multidisciplinary approach. In Forest insects as food: humans bite back. Edited by PB Durst, DV Johnson, RN Lesli \& K Shono. Food and Agriculture Organization of the United Nations, Thailand, Pp. 23-36.

Muralidharan R, Narasimhan D. 2012. Plants used for topical application from Gingee hills, Tamil Nadu, India. Current Botany 3(4): 49-52

Muruganandam S. 2016. Antioxidant and antidiabetic potentials of Mussaenda tomentosa. International Journal of Pharmacognosy and Phytochemistry Research 8(1): 64-70

Niveditha VR, Venkatramana DK, Sridhar KR. 2013. Cytotoxic effects of methanol extract of raw, cooked and fermented split beans of Canavalia on cancer cell lines MCF-7 AND HT-29. The IIOAB Journal 4(4): 20-23.

Paul D. 2011. Nutrient content of sexual and worker forms of the subterranean termite, Reticulitermes sp. Indian Journal of Traditional Knowledge 10(3): 505-507.

Rajan BKC. 1987. The wild fauna and human food. My Forest 23: 177-180.

Rasingam L. 2012. Ethnobotanical studies on the wild edible plants of Irula tribes of Pillur Valley, Coimbatore District, Tamil Nadu, India. Asian Pacific Journal of Tropical Biomedicine S1493-1497.

Revathi P, Parimelazhagan T. 2010. Traditional Knowledge on Medicinal plants used by the Irulas Tribes of Hasanur Hills, Erode District, Tamil Nadu, India. Ethnobotanical Leaflets 14: 136-60. 
Shafi PM, Rosamma MK, Jamil K, Reddy PS. 2002. Antibacterial activity of the essential oil from Aristolochia indica. Fitoterapia 73: 439-441

Shanbhag RR, Kabbaj M, Sundararaj R, Jouquet P. 2017. Rainfall and soil properties influence termite mound abundance and height: A case study with Odontotermes obesus (Macrotermitinae) mounds in the Indian Western Ghats forests. Applied Soil Ecology 111: 33-38.

Silambarasan R, Sureshkumar J, Ayyanar M. 2017. Traditional herbal medicines practiced by the ethnic people in Sathyamangalam forests of Western Ghats, India. European Journal of Integrative Medicine 16: 61-72.

Simonsen HT, Adsersen A, Smitt UW, Strasburg D, Jaroszewski JW. 2003. Methoxyflavones from Melicope borbonica and M. obscura. Biochemical and Systematic Ecology 31(3): 327-30.

Singh AJAR, Padmalatha C. 2004. Ethnoentomological practices in Tirunelveli district, Tamil Nadu. Indian Journal of Traditional Knowledge 3(4): 442-446.

Sinnu E. 2013. Living conditions of Irula tribes in Gingee taluk, Villupuram dist. of Tamil Nadu (India). Research Journal of Social Science and Management 3(2): 141-149.

Sun-Waterhouse D, Waterhouse GIN, You L, Zhang J, Liu Y, Ma L, Gao J, Dong Y. 2016. Transforming insect biomass into consumer wellness foods: A review. Food Research International 89(1): 129151.

Sureshkumar J, Silambarasan R, Ayyanar M. 2017. An ethnopharmacological analysis of medicinal plants used by the Adiyan community in Wayanad district of Kerala, India. European Journal of Integrative Medicine 12: 60-73.

Tan HSG, Verbaan YT, Stieger M. 2017. How will better products improve the sensory-liking and willingness to buy insect-based foods? Food Research International 92: 95-105.

Thurston E. 2013. Castes and Tribes of Southern India, Volume 2 of 7 . Government Press, madras, India.

van Huis A, Van Itterbeeck J, Klunder H, Mertens E, Halloran A, Muir G, Vantomme P. 2013. Edible insects - Future prospects for food and feed security. FAO of the United Nations, Rome Forestry Paper 171.

Wilsanand V. 2005. Utilization of termite Odontotermes formosanus by tribes of south India in medicine and food. Natural Product Radiance 4(2): 121-125.

Wu T, Huang S, Lai J, Teng C, Ko F, Kuoh C. 1993. Chemical and antiplatelet aggregative investigation of the leaves of Clausena excavata. Phytochemistry 32(2): 449-451.

Zielinska E, Baraniak B, Karas M, Rybczynska K, Jakubczyk A. 2015. Selected species of edible insects as a source of nutrient composition. Food Research International 77: 460-466. 